INTEGRITAS : Jurnal Pengabdian

Vol 5 No 1 Juli 2021

ISSN $2580-7978$ (cetak) ISSN 2615 - 0794 (online)

\title{
PENERAPAN METODE PARTICIPATORY RURAL APPRAISAL (PRA) PADA SUSU KEDELAI DI DESA KUTAGANDOK
}

\section{APPLICATION OF PARTICIPATORY RURAL APPRAISAL (PRA) METHODS ON SOYBEAN MILK IN THE KUTAGANDOK VILLAGE}

\author{
Naura Mutia Astari ${ }^{1)}$, Vita Efelina ${ }^{2)}$ \\ ${ }^{1,2}$ Program Studi Teknik Industri, Fakultas Teknik, Universitas Singaperbangsa Karawang \\ ${ }^{1}$ Email: nauramutia131@gmail.com
}

\begin{abstract}
Abstrak: Stunting pada anak masih menjadi masalah besar di Indonesia, berdasarkan pantauan status gizi (PSG) tahun 2017 bahwa 29,6\% kasus stunting, diatas ketetapan WHO (20\%). Faktor penyebab kasus Stunting pada balita sering di kaitkan dengan factor kemiskinan termasuk gizi, kesehatan, sanitasi dan lingkungan. Desa Kutagandok merupakan desa yang mengalami gizi krosnis atau stunting, salah satu upaya masyarakat desa dengan memberikan asupan gizi melalui susu kedelai. Susu kedelai memiliki gizi yang baik dapat dijadikan alternatif dari susu sapi karena memiliki kandungan protein yang hampir setara. Selain itu susu kedelai memiliki potensi yang memiliki harga nilai jual, oleh karena itu produk susu kedelai dijadikan sebagai produk UMKM Desa Kutagandok, upaya ini dapat meminimalisir stunting dan meningkatakan perkekonomian masyarakat desa. Berbagai program pemerintah maupun non pemerintah mengupayakan peningkatan perokonomian masyarakat, salah satunya Program Hibah Bina Desa (PHBD). Tujuan pada program hibah bina desa yaitu menjadikan produk susu kedelai menjadi produk UMKM, dengan harapan dapat meningkatkan pemasukan masyarakat desa. Untuk dapat mencapai tujuan digunakan metode pelaksanaan dengan pendekatan Participatory Rural Appraisal (PRA) yang merupakan pendekatan yang mengedepankan hasil perumusan sesuai dengan kebutuhan dalam penyelenggaraan program.
\end{abstract}

Kata Kunci : Susu kedelai, Metode participatory rural appraisal

Abstract: Stunting in children is still a big problem in Indonesia, based on the monitoring of nutritional status (PSG) in 2017 that $29.6 \%$ of cases of stunting are above the provisions of the WHO (20\%). Factors that cause stunting in children under five are often linked to poverty, including nutrition, health, sanitation and the environment. Kutagandok Village is a village that experiences critical nutrition or stunting, one of the efforts of the village community by providing nutritional intake through soy milk. Soy milk has good nutrition and can be used as an alternative to cow's milk because it has almost equivalent protein content. In addition, soy milk has the potential to have a selling value, therefore soy milk product is used as a product of UMKM in Kutagandok Village, this effort can minimize stunting and improve the economy of the village community. Various government and non-government programs seek to improve the economy of the community, one of which is the 
INTEGRITAS : Jurnal Pengabdian

Vol 5 No 1 Juli 2021

ISSN $2580-7978$ (cetak) ISSN 2615-0794 (online)

Program Hibah Bina Desa (PHBD). The goal of the village development grant program is to make soy milk products into UMKM products, with the hope that it can increase the income of the village community. In order to achieve the goal, an implementation method with the Participatory Rural Appraisal (PRA) approach is used, which is an approach that puts forward the formulation results according to the needs in program implementation.

Keywords : Soybean milk, Participatory rural appraisal (pra) methods

\section{PENDAHULUAN}

Indonesia merupakan negara dengan populasi penduduk keempat di dunia, dengan jumlah populasi yang di perkirakan pada tahun 2019 adalah 267 juta, dengan jumlah penduduk anak-anak (0-14 tahun) sebanyak 24,8\% dari jumlah keseluruhan populasi (Kementrian perencanaan pembangunan nasional, 2019). Namun, stunting pada anak masih menjadi masalah besar, berdasarkan pantauan status gizi (PSG) tahun 2017 bahwa 29,6\% kasus stunting, diatas ketetapan WHO (20\%). Stunting merupakan kondisi pada anak khususnya balita yang mengalami gagal pertumbuhan (pertumbuhan tubuh dan otak) yang di akibatkan oleh kekurangan gizi dalam waktu yang cukup lama. Penyebab terjadinya stunting adalah kurangnya akses terhadap makanan bergizi, rendahnya asupan makanan yang bervitamin dan mineral, selain itu kurangnya konsumsi pangan dan sumber protein hewani (Kementrian Kesehatan, Republik Indonesia,2018).

Stunting pada balita sering di kaitkan dengan faktor kemiskinan termasuk gizi, kesehatan, sanitasi dan lingkungan. Terdapat lima faktor utama penyebab stunting adalah kemiskinan, sosial budaya, meningkatnya paparan penyakit infeksi, kerawanan pada pangan dan akses pelayasan kesehatan yang kurang memadai. Faktor yang terjadi pada kasus gizi kronis pada balita disetiap wilayah perkotaan maupun pedesaan tidak lah sama, sehingga cara atau upaya penanggulangan harus disesuaikan dengan faktor yang yang terjadi di wilayah tersebut (Ridwan et al., 2019).

Stunting terjadi di beberapa daerah di Indonesia salah satunya Kabupaten Karawang sebanyak 13\% dari jumlah 116.000 balita, dapat di artikan dari 10 balita terdapat satu balita yang mengalami stunting. Dari 54 Desa Stunting di Kabupaten Karawang, 
INTEGRITAS : Jurnal Pengabdian

Vol 5 No 1 Juli 2021

ISSN 2580- 7978 (cetak) ISSN 2615-0794 (online)

salah satunya Desa Kutagandok, Kecamatan Kutawaluya (Kepala Dinas Kesehatan Kabupaten Karawang, 2019). Berdasarkan hasil wawancara oleh Kepala Desa bahwa masyarakat Desa Kutagandok merupakan masyarakat yang mayoritas mata pencahariannya adalah petani, peternak, dan buruh. Sehingga secara kondisi perekonomiannya mayoritas menengah ke bawah. Latar belakang pendidikan masyarakat Desa Kuta Gandok mayoritas telah menempuh pendidikan SMK, namun tidak sedikit yang melanjutkan pendidikannya sampai ke Perguruan Tinggi. Angka pengangguran di Desa Kuta Gandok masih tinggi. Lokasi Desa Kuta Gandok berada cukup jauh dari pusat kota Karawang, yaitu berjarak sekitar 24km dan membutuhkan waktu kurang lebih 1 jam perjalanan dengan menggunakan sepeda motor untuk tiba desa tersebut.

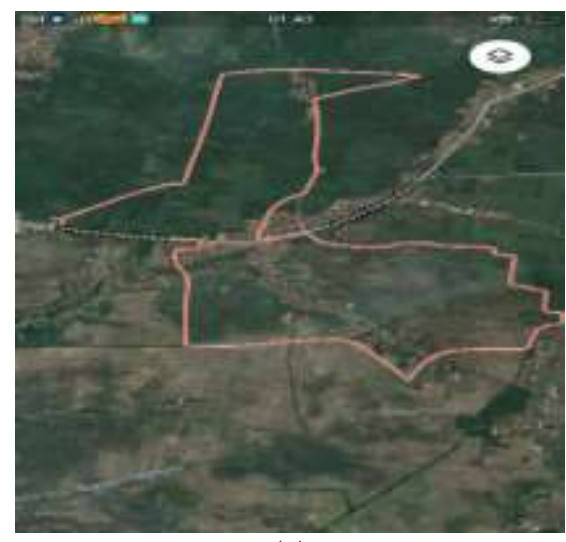

(a)

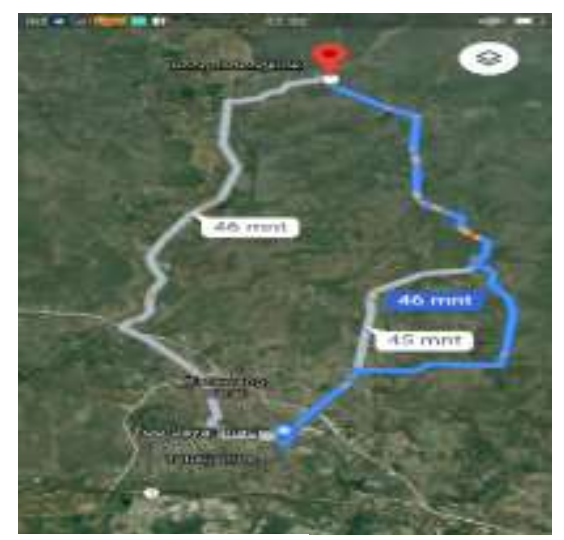

(b)

Gambar 1. (a) Luas wilayah Desa Kutagandok, (b) Jarak Pusat Kota Karawang dengan Desa Kutagandok

Banyak upaya yang dilakukan oleh pemeritah untuk menanggulangi stunting, termasuk Desa Kutagandok yang memberikan asupan gizi melalui susu kedelai yang di produksi oleh ibu-ibu PKK. Susu kedelai merupakan minuman yang berbahan baku kedelai sebagai alternatif susu sapi. Susu kedelai memiliki kandungan protein yang setara dengan susu sapi yaitu 3,5 g/100g, terdapat kandungan vitamin dan mineral yang lebih rendah dari susu sapi. Selain itu susu kedelai tidak mengandung laktosa yang cocok digunakan oleh penderita intoleransi laktosa dan susu kedelai rendak lemak (25g/100g) (Nirmagustina et al., 2013). Susu kedelai merupakan hasil 
ekstraksi biji kedelai yang mengadung serat, asam lemak tak jenuh serta protein tinggi yang hampir setara dengan susu sapi. Susu kedelai dapat menjadi alternative susu sapi bagi penderita lactose intolerance, di Indonesia populasi penderita sekitar $60-70 \%$, maka dibutuhkanya pengembangan produk susu bebas laktosa. Susu kedelai selain kaya dengan khasiatnya, secara bahan baku mudah ditemukan dan harga lebih terjangkau dibandingkan susu sapi (Fathurohman et al., 2020)

Susu kedelai selain sebagai alternative pengganti susu sapi sebagai upaya meminimalisir tingkat stunting, selain itu susu kedelai memiliki potensi untuk menjadi produk UMKM Desa Kutagandok untuk membantu perekonomian masyarakat. Hal ini di perkuat dengan bahan baku yang mudah di dapatkan, susu kedelai cukup popular dan harga susu kedelai lebih terjangkau dibandingkan susu sapi di pasaran (Rohmani et al., 2018). UMKM sudah di atur Undang-Undang Nomor 20 tahun 2008 tentang Usaha Mikro,Kecil dan Menengah, dapat diartikan bahwa UMKM merupakan usaha produktif yang dikelola oleh perorangan atau badan usaha perorangan yang memiliki kekayaan bersih dibawah lima puluh juta rupiah (tidak termasuk biaya lokasi/bangunan dan tanah) dan memiliki penghasilan penjualan tahunan tidak lebih dari tiga ratus juta rupiah. UMKM berdampak cukup besar dalam jumlah investasi asing pada sektor makanan dan minuman, pada tahun 2014 investasi industry makanan dan minuman mencapai 31,4 triliun rupiah atau $14,1 \%$ dari total seluruh sektor penanaman modal (Nirmagustina et al., 2013). Oleh karena itu, dengan adanya produk susu kedelai sebagai produk UMKM Desa Kutagandok, dapat meningkatkan perekonomian masyarakat.

Peningkatan perekonomian masyarakat dapat dilakukan jika masyarakat mengikuti perkembangan dan mampu beriringan dengan perubahan zaman. Agar masyarakat dapat mengikuti pekembangan zaman, berbagai program di pemerintah maupun non pemerintah dilaksanakan, salah satunya Program Hibah Bina Desa oleh mahasiswa. Program Hibah Bina Desa (PHBD) merupakan program Kemenristekdikti, yang dilakukan oleh mahasiswa melalui Unit Kegiatan Mahasiswa (UKM) dan atau Lembaga Eksekutif Mahasiswa. Harapan pada program ini dapat 


\section{INTEGRITAS : Jurnal Pengabdian}

Vol 5 No 1 Juli 2021

ISSN 2580- 7978 (cetak) ISSN 2615-0794 (online)

menumbuhkan rasa peduli dan berkontribusi kepada masyarakat desa agar terbangun desa bina aktif, mandiri, berwirausaha dan sejahtera (Kemenristekdikti, 2019). Untuk dapat mencapai tujuan digunakan metode pelaksanaan dengan pendekatan Participatory Rural Appraisal (PRA) yang merupakan pendekatan yang mengedepankan hasil perumusan sesuai dengan kebutuhan dalam penyelenggaraan program (Ridwan et al., 2019).

Pendekatan Participatory Rural Appraisal (PRA) didapatkan perumusan permasalahan berdasarkan hasil wawancara yang telah dilakukan team antara lain keterbatasan sumber daya manusia, kurangnya pengetahuan tentang pengelolaan dan pengemasan susu kedelai, akibatnya susu kedelai mudah basi menyebabkan kerugian. Proses produksi susu kedelai dilakukan manual, dimulai dari pengupasan kulit ari kedelai dengan cara manual sangat membutuhkan waktu yang lama, dan mempengaruhi pada kualitas susu yaitu bau langu (beaty flavor) yang merupakan bau khas dari susu kedelai yang berasal dari kulit ari kedelai (Tuhumury, 2015). Selanjutnya dilakukan penyaringan susu kedelai dengan ampasnya secara manual dengan cara di ayak menggunakan kain yang dilakukan oleh dua orang, pada proses ini yang menentukan tahanan lamanya susu kedelai. Melalui metode PRA, masyarakat desa bukan hanya menjadi objek penerima program (top-down), melaikan menjadi subjek pembangunan pada perencanaan dari bawah (bottom-up) dengan aktid dalam proses perencanaan penganggaran pelaksanaan dan pemanfaatan hasil pembangunan tingkat desa (Hudayana et al., 2019).

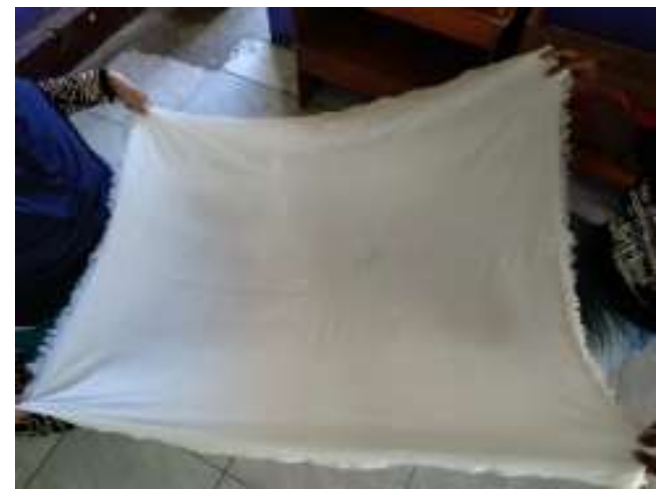

Gambar 2. Alat penyaring susu kedelai secara manual 
INTEGRITAS : Jurnal Pengabdian

Vol 5 No 1 Juli 2021

ISSN 2580 - 7978 (cetak) ISSN 2615 - 0794 (online)

\section{METODE}

Berdasarkan wawancara mengenai permasalahan yang ada maka didapatkan tujuan pada pelaksanaan yaitu memberikan wawasan atau pengetahuan mengenai susu kedelai dan pemasaran produk selain itu untuk meningkatkan kualitas susu kedelai dengan mengotomatiskan alat pengupas kulit ari kedelai dan penyaring susu kedelai.

Metode pelaksanaan yang digunakan dalam observasi UMKM Susu Kedelai adalah pendekatan Participatory Rural Appraisal (PRA) atau Pemahaman Partisipatif Kondisi desaan secara langsung, metode ini sangat cocok digunakan untuk mengidentifikasi situasi yang ada di masyarakat. Prinsip dasar pada PRA adalah berbagi pengalaman, keterlibatan masyarakat, penerapan konsep triangulasi dan keberlanjutan sebuah program (Mustanir et al., 2019). Selain itu pendekatan PRA dapat meningkatkan pemberdayaan masyarakat, dan bertujuan untuk perubahan sosial, budaya, kesejahteraan, maka dengan adanya metode PRA dapat berdampak pada pembangunan desa. PRA pada umumnya memiliki empat siklus yaitu perencanaan, tindakan, pengamatan dan refleksi (Ridwan et al., 2019). Metode PRA yang di terapkan pada UMKM susu kedelai memiliki beberapa tahapan, adalah:

1. Identifikasi Masalah

2. Analisis Kebutuhan

3. Penyusunan Program

4. Pelaksanaan Program

5. Monitoring dan Evaluasi

\section{HASIL DAN PEMBAHASAN}

Pelaksanaan kegiatan merupakan Program Hibah Bina Desa Universitas Singaperbangsa Karawang tahun 2019, waktu program berlangsung 6 bulan (bulan Juni 2019 sampai dengan Desember 2019). Kegiatan pengabdian berlokasi di Desa Kutagandok, Kecamatan Kutawaluya, Kabupaten karawang, kegiatan ini diikuti oleh 2 dusun dengan sasaran peserta yaitu ibu ibu PKK dan di dapat jumlah peserta 47 orang. Pada Program Hibah Bina Desa (PHBD) menghadirkan Stakeholder program yaitu 
INTEGRITAS : Jurnal Pengabdian

Vol 5 No 1 Juli 2021

ISSN $2580-7978$ (cetak) ISSN 2615-0794 (online)

Tim Pelaksana PHBD, Dosen Pembimbing, Civitas Academika, Kepala Desa, Ketua UMKM susu kedelai serta masyarakat (ibu ibu PKK). Pelaksanaan kegiatan dilakukan berdasarkan hasil observasi langsung selama kegiatan tujuan kebutuhan pada produksi susu kedelai. Dengan menerapkan metode pendekatan Participatory Rural Appraisal (PRA) didapatkan hasil kegiatan dibawah ini;

1. Identifikasi Masalah

Pada pertemuan pertama di lakukan identifikasi masalah mengenai UMKM susu kedelai bersama kepala desa dan wakil kepala desa, serta dihadiri oleh perwakilan ibu PKK. Diketahui bahwa permasalahan pada produksi susu kedelai yaitu kurangnya keterampilan dan pengetahuan mengenai susu kedelai, susu kedelai mudah basi, proses produksi memakan waktu yang lama dan pemasaran produk. Dalam pembuatan produk susu kedelai masyarakat di desa Kutagandok menggunakan cara manual dalam pembuatannya. Mulai dari pembuatan awal hingga pengemasan dilakukan secara manual sehingga dalam pembuatannya membutuhkan waktu dan tenaga yang besar. Dengan hal itu akan membuat pekerjaan menjadi tidak efektif dan efisien yang akan mempengaruhi kualitas dari produk susu kedelai.
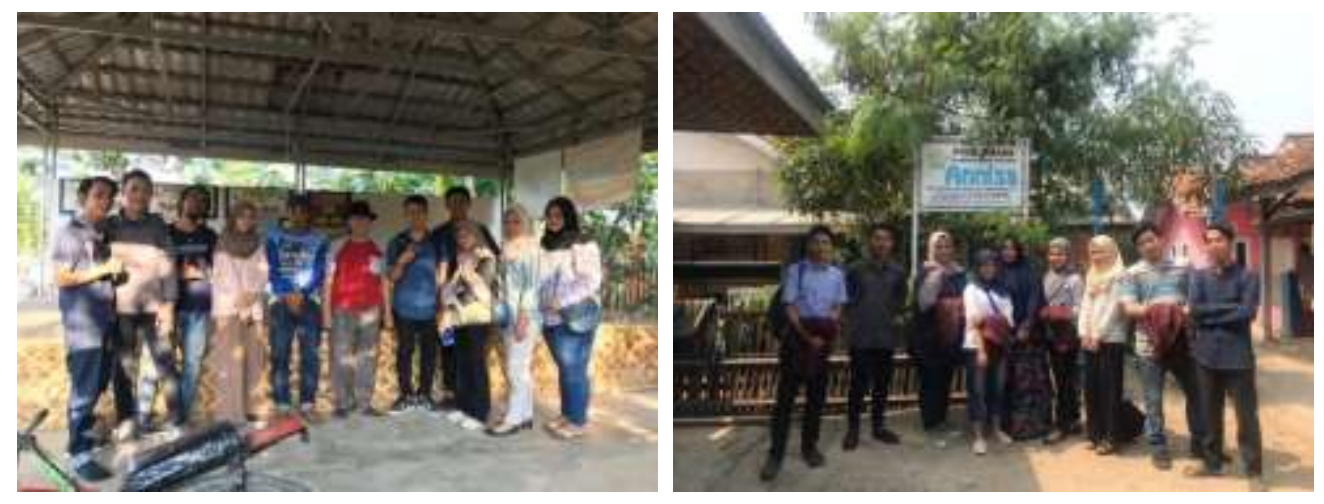

Gambar 3. Dokumentasi sosialisai dan diskusi UMKM susu kedelai

2. Analisis Kebutuhan

Keterlibatan masyarakat dalam pelaksanaan menghasilkan kebutuhan prioritas dalam program ini. Setelah diketahui permasalahanya pada UMKM susu 
kedelai maka analisis kebutuhan adalah dilakukan seminar dan pelatihan untuk mengasah keterampilan dan menambah pengetahuan mengenai susu kedelai, selanjutnya untuk menunjang kebutuhan susu kedelai berinovasi dengan mengganti pekerjaan yang dilakukan manual dengan mengotomasikan alat penyaring dan pengupas kulit ari dengan semi otomatis. Dengan alat tersebut akan membantu pada saat penyaringan susu kedelai yang lebih higienis, untuk menjaga kualitas susu kedelai. Selain itu permasalahan lainnya yaitu pemasaran produk dengan mempromosikan dalam dimedia online maupun offline,menganti kemasan pada produk yang awalnya dikemas dengan menggunakan plastik menjadi botol plastik.

3. Penyusunan Program

Penyusunan program untuk menyesuaikan waktu kegiatan program selama 6 bulan agar seluruh rangkaian kegiatan berjalan sesuai dengan tujuan kegiatan yaitu membetuk UMKM susu kedelai. penyusunan program berguna untuk menyesuaikan waktu dengan menghadirkan Stakeholder program, yaitu mengundang beberapa pihak dosen pembimbing, civitas academika, kepala desa kutagandok, dan masyarakat (ibu-ibu PKK).

4. Pelaksanaan Program

Pelaksanaan program berdasarkan identifikasi masalah dan analisis kebutuhan yang telah didiskusikan, didapatkan bahwa masyrakat perlu adanya kesadaran bahwa susu kedelai merupakan produk yang memiliki harga jual dan manfaat pada kandungannya. Selanjutnya dilakukan pelatihan pada proses produksi dengan menggunakan alat semi otomatis agar produksi susu kedelai lebih efektif dan efisien.

a. Seminar

Pada tahap pertama dan pembukaan kegiatan program ini dengan memberikan pemahaman kepada masyarakat Desa Kutagandok mengenai cara mengelola susu kedelai yang baik, gizi yang terdapat pada susu kedelai, manfaat yang terkandung dalam susu kedelai, serta memberikan pemahaman 
INTEGRITAS : Jurnal Pengabdian

Vol 5 No 1 Juli 2021

ISSN $2580-7978$ (cetak) ISSN 2615-0794 (online)

tentang bagaimana memasarkan suatu produk yang pada hal ini adalah susu kedelai yang disampaikan oleh beberapa pemateri, yaitu: Anggi Pasca Arnu, S.E., M.M (Sebagai pemateri Marketing susu kedelai), Milliyantri Elvandari, S.Gz., M.Si (Sebagai pemateri manfaat pada kandungan susu kedelai)

Selanjutnya, mendemontrasikan cara kerja alat susu kedelai semiotomatis dalam penggunaan serta perawatannya kepada masyarakat Desa Kutagandok. Acara Bimbingan Seminar dihadiri oleh perwakilan Stakeholder program, bapak H.Wahyudin ST.,MT sebagai perwakilan civitas akademika, dosen pembimbing ibu Vita Efelina S.Si.,M.Sc dan kepala desa kutagandok bapak H.Adang. Dengan jumlah peserta yang hadir dalam acara 47 Peserta dari ibu ibu PKK sebagai masyarakat kutagandok.
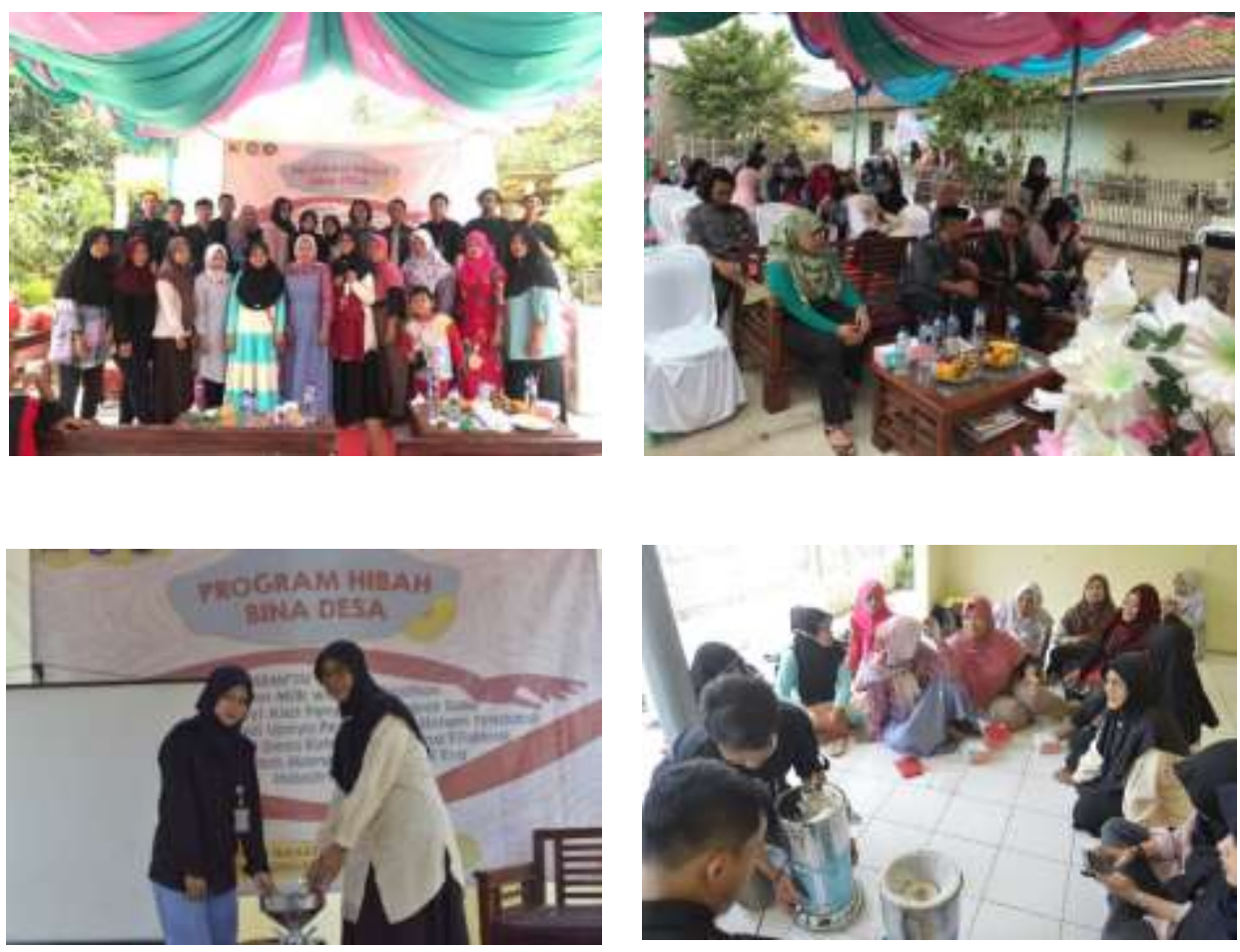

Gambar 5. Dokumentasi kegiatan seminar 
INTEGRITAS : Jurnal Pengabdian

Vol 5 No 1 Juli 2021

ISSN $2580-7978$ (cetak) ISSN 2615-0794 (online)

b. Pelatihan

Tahap pelatihan dan produksi dengan menggunakan alat semi-otomatis dilakukan agar masyarakat terampil dalam mengoprasikan alat. Selain itu membandingkan hasil produksi secara manual dan menggunakan alat, didapatkan bahwa menggunakan alat hasil produksi lebih kental dan wangi khas dari susu kedelai berkurang. Selanjutnya mengganti kemasan platik dengan kemasan botol plastik dengan memberikan label keterangan produk. Penggunakan kemasan yang menarik dan mengkomersialisasikan produk susu kedelai ke berbagai warung dan toko yang berada di Desa Kutagandok.

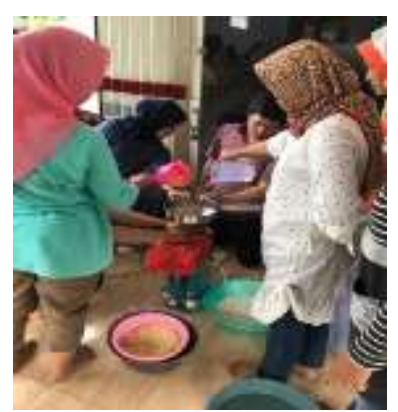

(a)

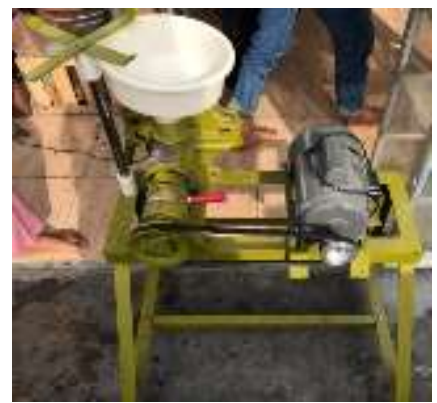

(c)

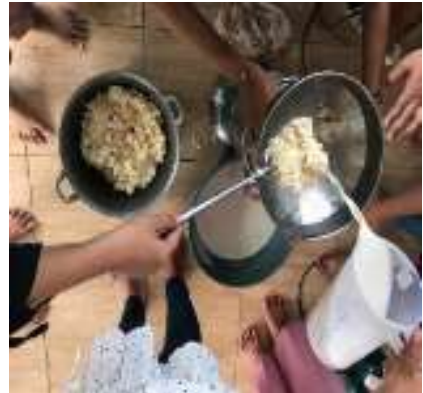

(b)

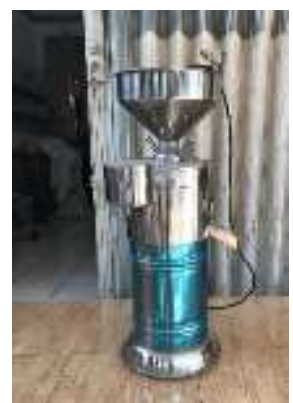

(d)

Gambar 6. (a) dan (b) Kegiatan pelatihan pembuatan susu kedelai dengan alat semi otomatis (c) Alat pegupas kulit ari dan (d) Alat penyaring susu kedelai

\section{Monitoring dan Evaluasi}

Pada tahap ini masyarakat sudah dapat memproduksi susu kedelai secara mandiri, maka dilakukan monitoring kegiatan untuk mengetahui keberlanjutan produksi susu kedelai dan hambatan pada produksi susu kedelai. Dalam proses 
INTEGRITAS : Jurnal Pengabdian

Vol 5 No 1 Juli 2021

ISSN 2580-7978 (cetak) ISSN 2615-0794 (online)

pembuatan susu kedelai menggunakan alat tradisional dalam prosesnya membutuhkan waktunya yang cukup lama yaitu sekitar 6 sampai 7 jam dikarenakan proses produksinya masih menggunakan cara manual yaitu dengan pengupasan kulit ari kedelai menggunakan tangan dan penyaringan ampas susu kedelai yang masih menggunakan kain yang diayak sehingga berdampak pada proses produksinya yang lama. Namun dalam pembuatan susu kedelai menggunakan alat semi otomatis waktu dalam proses produksi bisa lebih cepat yaitu sekitar 3 sampai 4 jam. Awalnya susu kedelai hanya di produksi di waktu tertentu, namun setelah adanya program ini, ibu UMKM menargetkan Produksi sebanyak 3 kali/ minggu dengan jumlah produksi 1 minggu/60 Liter . Sehingga bisa dapat menambah pendapatan pada ibu ibu UMKM. Produk susu kedelai sudah diikut sertakan pada kegiatan Bazar Kecamatan Kutawaluya dan acara Dinas kesehatan di Desa Kutagandok sebagai bentuk pemasaran produk agar lebih luas.

Evaluasi pada produk susu kedelai terdapat hal hal yang belum bisa diatasi seperti produsen kemasaran dan perawatan mesin yang berada jauh dari desa, serta pemsaran produk belum dapat dilakukan secara meluas karena belum adanya izin PIRT dari Dinas Kesehatan.
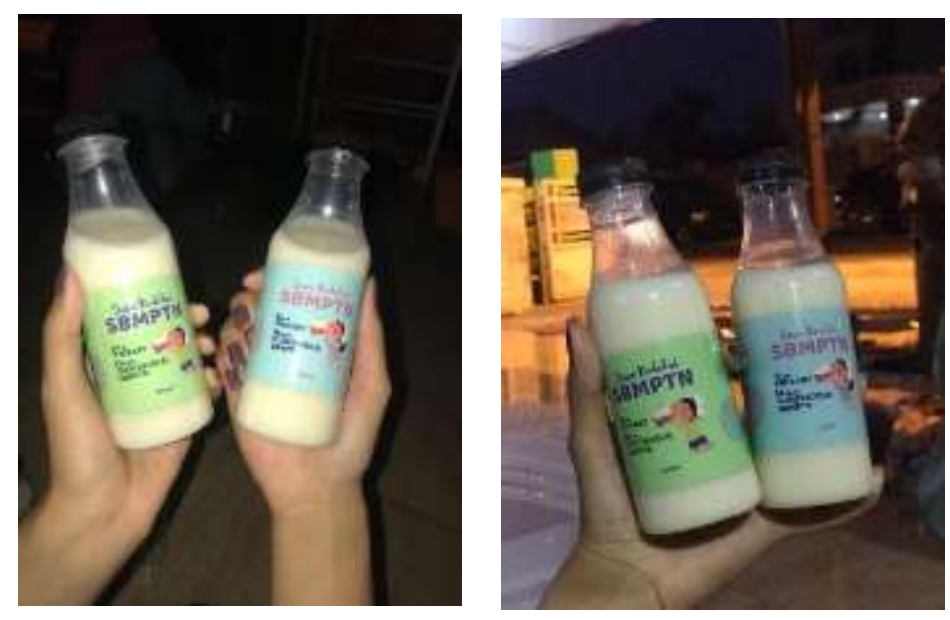

Gambar 7. Produk UMKM susu kedelai 
INTEGRITAS : Jurnal Pengabdian

Vol 5 No 1 Juli 2021

ISSN $2580-7978$ (cetak) ISSN 2615 - 0794 (online)

\section{KESIMPULAN}

Kesimpulan pada pendekatan PRA didapatkan perencanaan yaitu dengan mengidentifikasi masalah selanjutnya diketahui analisis kebutuhan pada UMKM susu kedelai, setelah kebutuhan di penuhi dilakukan penyusunan program untuk menyesuaikan waktu kegiatan. Tindakan pada UMKM susu kedelai yaitu pelaksanaan program yang di lakukan dua tahap yaitu pertama Seminar sebagai bentuk pengetahuan mengenai susu kedelai dan pemasaran pada produk, tahap yang kedua adalah pelatihan penggunaan alat semi otomatis penyaring susu kedelai dan pengupas kulit ari. Monitoring dan Evaluasi dilakukan sebagai bentuk pendampingan agar program dapat terus berjalan selain itu untuk melihat kendala yang dirasakan setelah pelaksanaan program. Manfaat yang di rasakan adalah kemajuan pada jumlah produksi 3kali/perminggu, dengan jumlah produksi 60L/minggu. Selain itu waktu produksi lebih singkat yaitu membutuhkan waktu 3-4jam waktu produksi. Dapat disimpulkan penerapan metode PRA cukup efektif untuk dilakukan pada pengabdian desa yang dilakukan di Desa Kutagandok dengan produk susu kedelai, kegiatan program terlaksana sesuai dengan luaran harapan atau tujuanyaa.

\section{UCAPAN TERIMAKASIH}

Ucapan Terimakasih kepada Direktorat Kemahasiswaan, Direktorat Jenderal pembelajaran dan Kemahasiswaan, Kementrian Riset, teknologi dan pendidikan atas bantuan pendanaan dan kesempatan yang diberikan kepada kami untuk mengikuti Program Hibah Bina Desa (PHBD) 2019. Terimakasih kepada Kepala Desa serta masyarakat Desa Kutagandok telah bersedia menjadi tempat untuk pengabdian desa.

\section{DAFTAR PUSTAKA}

Fathurohman, M., Aprillia, A. Y., Pratita, A. T. K., \& Tenderly, V. F. (2020). Diversifikasi Produksi Susu Kedelai Berbasis Mikroalga Autotrofik Guna Meningkatkan Indeks Nutraseutikal. Jurnal Aplikasi Teknologi Pangan, 9(2), 70-76. https://doi.org/10.17728/jatp.6150.

Hudayana, B., Kutanegara, P. M., Setiadi, S., Indiyanto, A., Fauzanafi, Z., Nugraheni, M. D. F., Sushartami, W., \& Yusuf, M. (2019). Participatory Rural Appraisal (PRA) untuk Pengembangan Desa Wisata di Pedukuhan Pucung, 
INTEGRITAS : Jurnal Pengabdian

Vol 5 No 1 Juli 2021

ISSN $2580-7978$ (cetak) ISSN 2615-0794 (online)

Desa Wukirsari, Bantul. Bakti Budaya, 2(2), 3. https://doi.org/10.22146/bb.50890.

Kemenristekdikti. (2019). Pedoman Program Hibah Bina Desa (Phbd). Journal of Chemical Information and Modeling, 26. http://phbd.ristekdikti.go.id

Mustanir, A., Hamid, H., \& Syarifuddin, R. N. (2019). Pemberdayaan Kelompok Masyarakat Desa Dalam Perencanaan Metode Partisipatif. Moderat: Jurnal Ilmiah Ilmu Pemerintahan, 5(3), 227-239.

Nirmagustina, D. E., Hertini Rani, Studi Teknologi Pangan, P., \& Negeri Lampung, P. (2013). Pengaruh Jenis Kedelai dan Jumlah Air terhadap Sifat Fisik, Organoleptik dan Kimia Susu Kedelai. Jurnal Teknologi Industri Dan Hasil Pertanian, 18(2), 168-174.

Ridwan, I., Dollo, A., \& Andriyani, A. (2019). Implementasi Pendekatan Participatory Rural Appraisal pada Program Pelatihan. Journal of Nonformal Education and Community Empowerment, 3(2), 88-94. https://doi.org/10.15294/pls.v3i2.34913.

Rohmani, S., Yugatama, A., \& Prihapsara, F. (2018). Inovasi Minuman Sehat Berbahan Kedelai dalam Upaya Pemberdayaan Masyarakat melalui Wirausaha di Kabupaten Sukoharjo ( Innovations Healthy Drinks in Source of Soybean in Community Empowerment through Entrepreneurship in Sukoharjo District ). Agrokreatif, Jurnal Ilmiah Pengabdian Kepada Masyarakat, 4(1), 68-74.

Tuhumury, H. C. D. (2015). Effect of Soy Isoflavones on the Serum Lipid Profile and Vascular Function. AGRITEKNO: Jurnal Teknologi Pertanian, 4(1), 1-7. https://doi.org/10.30598/jagritekno.2015.4.1.1. 